\title{
Initiating an antimicrobial stewardship program with limited resources
}

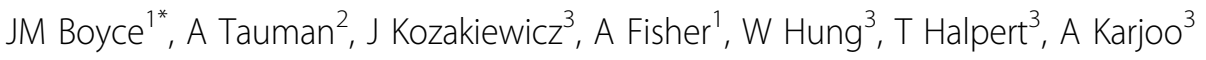 \\ From International Conference on Prevention \& Infection Control (ICPIC 2011) \\ Geneva, Switzerland. 29 June - 2 July 2011
}

\section{Introduction / objectives}

Antimicrobial stewardship (AMS) is an important strategy for improving patient safety, but many hospitals have limited resources to devote to AMS. We describe formation of an AMS program in a 400-bed hospital with relatively limited resources.

\section{Methods}

We developed an AMS program, headed by a pharmacist and infectious diseases (ID) physician. Drug utilization reviews identified an expensive, broad-spectrum agent (piperacillin-tazobactam [P-T]) for initial targeting. An AMS form for listing clinical data and recommendations was developed. A daily list of patients receiving $\mathrm{P}-\mathrm{T}$ was used to identify target patients for intervention. The pharmacist and ID physician made rounds on wards, placed AMS forms in patient charts, and spoke to caregivers regarding recommendations. Intravenous to oral conversions were performed by pharmacists. After 6 months of AMS activity revealed cost savings, hospital administration approved a $1 / 2$-time pharmacist position for AMS.

\section{Results}

In the first complete year of the AMS program, the hospital spent $\$ 277,833$ less on anti-infectives (11\% reduction in cost/adjusted patient-day) than in the previous year. Of this amount, $\$ 172,865$ less was spent specifically for broad-spectrum agents (22\% reduction in cost/ adjusted patient-day for broad-spectrum agents). P-T purchases decreased by $20 \%$, levofloxacin by $10 \%$ and vancomycin by $19 \%$ compared to the previous year. $90 \%$ of recommendations were accepted by caregivers. The number of new, nosocomial Clostridium difficile

${ }^{1}$ Medicine, Hospital of Saint Raphael, New Haven, USA

Full list of author information is available at the end of the article diarrhea cases $/ 10,000$ patient-days decreased by $28 \%$ compared to the previous year.

\section{Conclusion}

An AMS program implemented with relatively few resources resulted in cost savings to the hospital and improved patient care.

\section{Disclosure of interest}

None declared.

\section{Author details}

${ }^{1}$ Medicine, Hospital of Saint Raphael, New Haven, USA. ${ }^{2}$ VHA, Southport, CT, USA. ${ }^{3}$ Pharmacy, Hospital of Saint Raphael, New Haven, USA.

Published: 29 June 2011

doi:10.1186/1753-6561-5-S6-041

Cite this article as: Boyce et al:: Initiating an antimicrobial stewardship program with limited resources. BMC Proceedings 2011 5(Suppl 6):041.

\section{Submit your next manuscript to BioMed Central and take full advantage of: \\ - Convenient online submission \\ - Thorough peer review \\ - No space constraints or color figure charges \\ - Immediate publication on acceptance \\ - Inclusion in PubMed, CAS, Scopus and Google Scholar \\ - Research which is freely available for redistribution

